\title{
Total Factor Productivity and the Bio Economy Effects
}

\author{
Carlos Alberto Zúniga González \\ National Autonomous University of Nicaragua, León \\ Dept. of Agroecology, Science and Technology Faculty \\ Researching Centre for Agrarian Sciences and Applied Economic \\ PO Box 68, Campus Agropecuario León, Nicaragua \\ E-mail: czuniga@ct.unanleon.edu.ni
}

Received: November 13, 2012 Accepted: November 24, 2012 Published: December 18, 2012 doi:10.5296/jas.v1i1.2383

URL: http://dx.doi.org/10.5296/jas.v1i1.2383

\begin{abstract}
This paper develops a new measure of total factor productivity growth in agricultural Production which incorporates Bio Economic components effects. The new measure is called the Bio Economic-Oriented Total Factor Productivity (BTFP) index, and incorporates components of Bio Economic as liquid biofuels. BTFP measure changes in Bio Economic efficiency and can be decomposed into bio economy efficiency change (BEC), and Bio Economic technological change (BTC) components.An empirical analysis, involving 7 Central American countries-level during 1980-2007, is provided using DEA methods. The results have shown a positive annual growth in bio economy total factor productivity of 1.1 percent. This change is explained by 0.03 percent per year in the bio economy efficiency change (or bio economy catch-up) and bio economy technical change (or bio ethanol frontier-shift) is providing 0.09 percent.
\end{abstract}

JEL Classification: D: 24, O: 13, O: 47, P: 51, Q: 10.

Keywords: Bio Economy Total Factor Productivity Growth, Malmquist Index, Data Envelopment Analysis, Bio-Economy, Bio-Ethanol.

\section{Introduction}

In Latin America the Bio Economy is a new perception that is being examined by a group of colleagues with the issue "The Bio Economy in Latin America and the Caribbean: Towards a socio economic research agenda” (Trigo, 2011).During the past three decades, the Bio Economic side effect of economic activities has received increasing attention in public debate where the environmental issues have been highlighting this debate (Hoang and Coelli, 2009). 
This paper intent to contribute to the efforts that other authors have been made to integrate Bio Economy concerns into traditional technical and socio economic performance measure, as well as made it in environmental concerns (Zúniga: 2011; Scheel, 2001; Tyteca, 1996).

Generally, these environmental performance measures are derived by making adjustments to standard parametric and non-parametric efficiency and productivity analysis techniques (Coelli, et al. 2007). The traditional approach that the majority of these studies have taken is that the environmental effect is modeled as either a bad output or an environmentally detrimental input in production models (e.g. Ball, et al. 1994; Färe, et al. 1989; Reinhard, et al. 2000; Shaik and Perrin 2001; Tyteca 1997). These methods, however, face two criticisms. First, they fail to allow for both increasing desirable output and reducing undesirable output at the same time (Chung, et al. 1997). Secondly, Coelli, et al. (2007) shows that these methods often do not satisfy the materials balances condition.

Chung, et al. (1997) proposed the use of a directional distance function which allows for simultaneous expansion of desirable output and contraction of undesirable output. While thismethod overcomes the first criticism, this approach also fails to satisfy the materials balancecondition, which we show later in this paper.

Recently, Coelli, et al. (2007) suggested the use of an alternative modeling approach that usesthe materials balance condition in deriving an environmental efficiency measure. Theyconsider the situation where the environmental pollution is caused by the balance of nutrients, equal to the difference between nutrients in inputs and nutrients in outputs. In order to reducepollution, one could reduce the nutrients balance by, for example, reducing the nutrient amountcontained in the input vector. Compared with the traditional approach, this method does notinvolve the introduction of any extra variables into the production model and satisfies thematerials balance condition.

In their study, the materials contents of inputs is treated in an analogous way to the way inwhich input prices are used in a standard cost efficiency calculation, and hence parametric and non-parametric techniques can be used to estimate the efficiency scores.

Given a fixed output vector, the environmental efficiency is defined as the ratio of the smallest technically feasible bio economic balance over the observed of Biofuels balance. The environmental efficiency can also be decomposed into technical efficiency (TE) and allocative efficiency (AE) components.

In this paper, the components of Biofuels are used to measure the Bio Economy productivity and efficiency of the national agricultural sector in Central America Countries in term of bioethanolas biofuels. I term this Bio Economy efficiency measure as Bio Economic-Oriented efficiency (BEE). I also construct a Bio Economy Total Factor Productivity (BTFP) index.This index is a Bio Economy adjusted Malmquist Productivity Index which incorporates the traditional total factor productivity (TFP) information along with Bio Economic components.

The remainder of this paper is organized into sections. In section 2, the Bio Economy and the role of biotechnology and the Methods of measuring bio economy performance are described. 
In section 3, the bio economic-oriented efficiency and productivity measures and biofuels oriented total factor productivity are described. In Section 4, the Bio economy in Central America applicationis described.In section 5, the DEA methodology for bio economy is described where the DEA, the Malmquist TFP for bio economy are used. In Section 6, the data used is described.In Section 7, refer conclusion and discuss of the results. Finally, in the final section, some concluding comments are made.

\section{The Bio Economy and the role of biotechnology}

The Bio Economic is today referred as a concept that can be synthesized such as "the application of knowledge in life sciences in new, sustainable, environmentally friendly, and competitive products" (EC, 2005), or as "the aggregate set of economic operations in a society that uses the latent value incumbent in biological products and processes to capture new growthand welfare benefits for citizens an nations" (OECD, 2006), or "encompassing all those sectors and their related services which produce, process or use biological resources" (OCDE, 2009).

In agricultural production the Bio Economy is about moving economies based on petroleum and their derivatives to fuels and materials that are renewables, environmentally friendly and of greater availability.The farmers as economic agents use many different inputs which contain some classification of bio economy together of modern chemistry and biology, materials sciences and information technology that consider the plant materials and other living organism (i.e Trichogramma as benefic insects).Moreover, the Bio Economic is about new ways of linking natural resources and processes to goods and services through increased knowledge intensity as a common denominator of the new value chains (Trigo, 2011).

The petroleum, gas and coal have been the basic source of energy as input of agricultural activities, but the high dependence have provided the base for an increased concern regarding the environmental sustainability, it goes into the environment through land, air or water and potentially causes pollution.Additionally, energy input intensification does not seem a coherent response in view of rising global climate change concerns, as high-input agriculture is - in many contexts - seen as one of the worst offenders in terms of $\mathrm{CO}_{2}$ emission. This is the basic source of biomass in the agriculture.

In this context, Bio Technology in its applications of techniques using living organism or substances derived from these organisms to make of modify a product, improve plants or animals or develop micro-organism for specific use to agricultural and to industrial productionwill certainly play of key role in solving the emerging conflicts (Cohen, 1994).

\section{Methods of measuring bio economy performance}

The Bioeconomy is a new issue in Latin America (LA), consequently is important to work on the address to identify and estimating the potential bioeconomy benefits for LA countries, specifically the Central America (in my case), and your impact into the productivity growth on the agricultural production system. 
Traditionally, undesirable outputs have often been ignored in production economics, it is the case of the bioeconomy where the studies are focused on the macroeconomic and microeconomic issue and where it is disregarded the bioeconomy effects into productivity growth.

However,recently there has developed a growing literature proposing different indicators linking environmental land economic performance of production activities where the bioeconomy is considered. On the topic ofbioeconomy,Rozakis and Sourie (2005) develop a partial equilibrium linear programming model of the French biofuels sector.Their goal was to make policy suggestions regarding the efficient allocation of land to bioenergy crops and efficient tax exemptions. Zhang, Vedenov, and Wetzstein (2007) develop a structural vector autoregressive model to examine if producers of methyl tertiary butyl ether (MTBE) engaged in limit pricing to prohibit growth of ethanol as a gasoline additive. They find support for this hypothesis, concluding that the U.S. ethanol industry is vulnerable to the import of less expensive sugarcane-based ethanol Elobeid et al. (2007) provide the first comprehensive model of the bio economy, and later Tokgoz et al. (2007) fill some gaps associated with the first article, including work on the equilibrium prices of co-products of the biofuel industries, most importantly distiller’s grains (Baker, Hayes and Babcock, 2008).

Concerning of environmental performance Tyteca (1996) stresses the potential usefulness of the efficiency measurement literature in dealing with these issues and makes available a detailed literature review of the different methods that have been used to measure environmental performance of organizations. In your paper spread-out a variety of issues connecting to the development of environmental performance indicators, including concerns about aggregation, normalization, standardization and accounting.

Pittman (1983) was one of the first to attempt to incorporate pollution into conventional productivity measures. He proposed an index number methodology that was derived from a theoretical model where the objective was the maximal radial expansion of desirable output sand contraction of undesirable outputs, holding the input vector constant. Färe, et al. (1989) used non-linear programming techniques to construct hyperbolic efficiency measures allowing for the expansion of desirable output and the reduction of pollution as an environmental detrimental input at the same time. This approach was used by Yaisawarng and Klein (1994) and Tyteca (1997) in industrial applications. Färe, et al. (1994) extended the workby Färe, et al. (1989) using parametric output distance functions to permit easier measurement of the shadow prices of the bad outputs.

Färe, et al. (1996) proposed an input distance function approach that could be used to decompose productive efficiency into input efficiency and environmental efficiency. More recently, Chung, et al. (1997) have used a directional distance function to estimate environmental efficiency and productivity measures.

In Färe, et al. (1996), for each firm two input-orientated DEA models were tracks. The first model is allowed for the conventional proportional contraction of all inputs given the level of desirable and undesirable outputs, with strong disposability assumed for all variables. The second model did the same thing, except it imposed weak disposability on undesirable 
outputs. The environmental indicator was then defined as the ratio of the efficiency scores obtained in the first and second models. Tyteca (1997) then further adapted the Färe, et al. (1989) to derive environmental efficiency scores by measuring the degree to which the pollution variable could be reduced given the fixed levels of inputs and desirable outputs.

In contrast to an output distance function which seeks to increase both desirable and undesirable outputs simultaneously, Chung, et al. (1997) proposed the use of a directional distance function which seeks to increase desirable output and reduce undesirable output at the same time. The authors suggested scaling the output vectors according to a vector of directions which could be flexibly selected. The direction vector they proposed was to increase desirable outputs and decrease undesirable outputs, in a manner proportional to the observed values for that firm. The paper also illustrated how one could decompose a total factor productivity change measure (that includes undesirable outputs) into efficiency change and technical change.

In an agricultural example, Reinhard, et al. (2000) studied the effects of nitrogen pollution on dairy farms in the Netherlands. The nitrogen balance calculated using the materials balance equation was the pollution variable of interest. This pollution variable was modeled as the environmental detrimental input variable in the production function. The first model involved the contraction of the pollution variable holding the conventional inputs and outputs constant. The second model allowed for the radial expansion of the outputs with the both the conventional inputs and pollution variable held constant. The third model was the input-orientated version of the second model, which scaled down the conventional and pollution input variables given the fixed level of outputs. These three models produced three types of efficiency scores: an environmental efficiency score, an output-orientated technical efficiency (TE) score and an input-orientated TE scores.

Coelli, et al. (2007) shows that most of efficiency measures described above do not satisfy the materials balance condition. This was done for groups of environmental efficiency measures which are based on input or output distance functions (i.e. Färe, et al. 1989); Färe, et al. (1996); Reinhard, et al. (2000)). In the following section we also show that the directional distance function proposed by Chung, et al. (1997) also fails to satisfy this condition.

\section{Bio Economic-Oriented efficiency and productivity measures}

Coelli, et al. (2007) utilize an alternative environmental efficiency measure that involves the incorporation of the materials balance condition into the production model. In these models, the desirable output vector was fixed and undesirable outputs were viewed as the net balance of bioeconomy component concern as defined in (1).

When $\mathrm{q}$ is fixed, the surplus balance is minimized when the aggregate input bioeconomy component concern content $\left(\mathrm{N}=\mathrm{a}^{\prime} \mathrm{x}\right)$ is minimized $^{1}$. In this method, instead of minimizing inputs, they minimized the aggregate contents contained in the input vectors. This is done on

\footnotetext{
${ }^{1}$ This excludes the case where the bio economy balance is negative. The reality is that there is the positive balance of biofuels used in agricultural production. The positive balance goes to the environment and makes the environment polluted. A positive balance is denoted as surplus.
} 


\section{Al Macrothink}

the grounds that a firm is more environmentally efficient if it produces a lower nutrient balance.

$$
N(q, a)=\min \left\{a^{\prime} x \mid(x, q) \in P\right\} \text { where } P \text { is the output set }
$$

The input vector that contains the minimum nutrient content is donated $x_{e}$ and the minimum nutrient content equals to $\mathrm{Ne}=\mathrm{a}^{\prime} \mathrm{x}_{\mathrm{e}}$. The nutrient content at the observed input vector is denoted $\mathrm{N}=\mathrm{a}^{\prime} \mathrm{x}$. The technically efficient input vector is denoted by $\mathrm{x}_{\mathrm{t}}$.

These three input vectors are illustrated in Figure 1, for the simple case where there are two input variables. The slopes of the iso-bioeconomy components lines reflect the ratios of bioeconomy components contents of the two inputs. The intercepts of these lines represent the total amount of bioeconomy $(\mathrm{N})$ contained in the input vectors $\mathrm{x}, \mathrm{x}_{\mathrm{e}}, \mathrm{x}_{\mathrm{t}}$. The iso-bioeconomy component line passing through the observed point $\left(\mathrm{x}_{1}, \mathrm{x}_{2}\right)$ has a larger intercept than the line passing through the technically efficient point $\left(\mathrm{x}_{1 \mathrm{t}}, \mathrm{x}_{2 \mathrm{t}}\right)$. Similarly the iso-bioeconomy component line passing through the technical efficient point has an intercept that is larger than the line passing through the bioeconomy component minimizing point $\left(\mathrm{x}_{1 \mathrm{e}}, \mathrm{X}_{2 \mathrm{e}}\right)$.

Next, I define bioeconomy components-orientated efficiency (BE), technical efficiency (TE) and bioeconomy components orientated allocative efficiency (BAE).

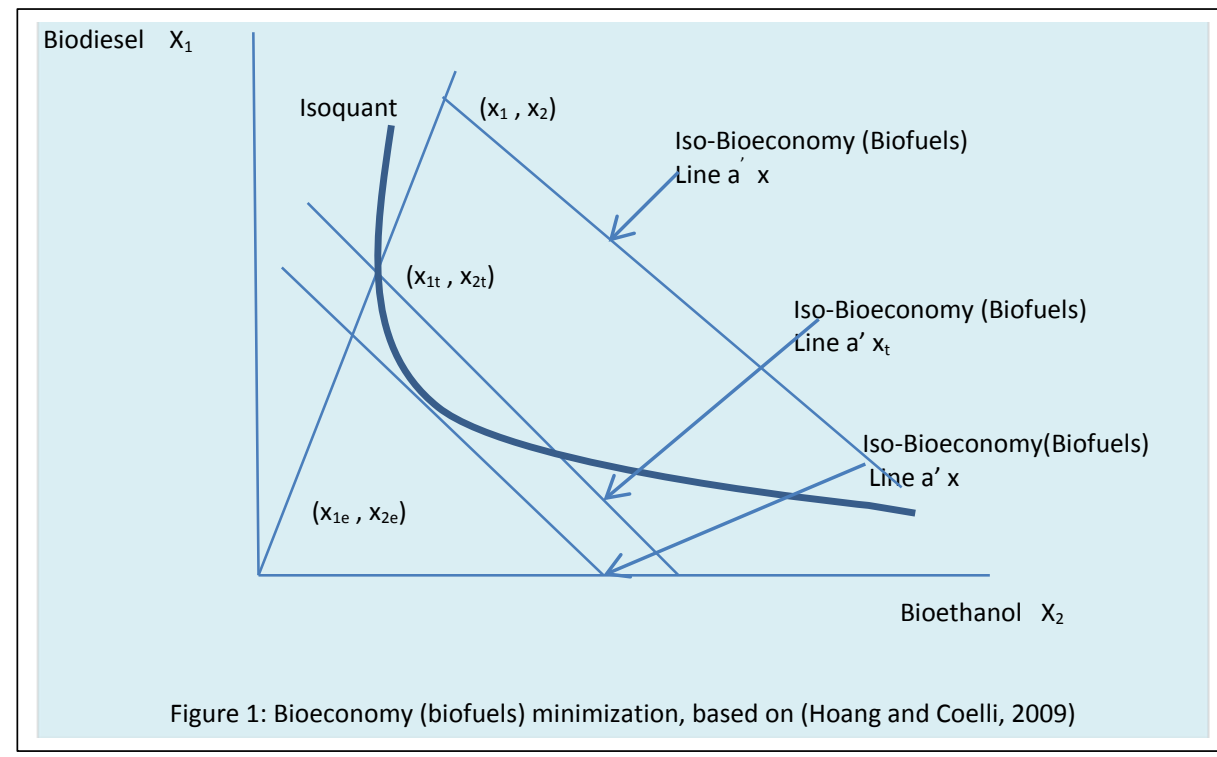

$$
\operatorname{TE}(\mathrm{q}, \mathrm{x})=\min _{\theta}\{\theta \mid(\theta x, q) \in Y\},
$$

where $\theta$ is a scalar taking a value between zero and one. The $x_{t}$ is the solution to this optimization problem. $\mathrm{B}_{\mathrm{t}}=\mathrm{a}^{\prime} \mathrm{x}_{\mathrm{t}}$ is defined as the Biofuels content at the technically efficient input vector and hence

$$
\mathrm{TE}=\frac{B_{t}}{B}=\frac{a^{\prime} x_{t}}{a^{\prime} x}=\theta,
$$


Following Coelli, et al. (2007), the Bioeconomy components-orientated efficiency measure (BE) of a firm is defined as the ratio of the minimum Bio economy component content over the observed Bio economy content:

$$
\mathrm{BE}=\frac{B_{e}}{B}=\frac{a^{\prime} x_{e}}{a^{\prime} x},
$$

BE then can be decomposed into technical efficiency (TE) and Bioeconomy component-orientated allocative efficiency (BAE):

$$
B E=T E x B A E,
$$

Where

$$
B A E=\frac{B_{e}}{B_{t}}=\frac{a^{\prime} x_{e}}{a^{\prime} x_{t}}
$$

BTE relates to the operation of the firm on the frontier of the production technology (i.e. the production possibility curve) while BAE relates to using the correct input mix given the observed nutrient contents. All three efficiency measures take values between zero and one.The value of unity indicates full efficiency while less than unity implies inefficiency.

As noted in Coelli, et al. (2007), BE can be estimated following a procedure similar to estimating cost efficiency in which the vector of nutrient contents of the inputs (a) is used instead of prices.

There are some advantages of using this nutrient-orientated efficiency measure. First, in the setting of distance functions and frontier functions (i.e. revenue, cost or profit functions), this approach allows the estimation of shadow prices of nutrient reduction and the estimation of effects on nutrient reduction by policy changes (e.g. taxation). This was discussed in Coelli, et al. (2007).

The second advantage is that these Bioeconomy component-orientated efficiency and productivity measures are applicable to the analysis of both individual Bioeconomy component flow and aggregate flow of various components. In agricultural production, for example, there are concerns on the balances of various things, such as biogas, Ethanol, Biofuels, Biodiesel and Bioenergy. This approach canquantify bioeconomy efficiency and productivity measures by applying the Bioeconomy components to the balance of different individual Bioeconomy or to the aggregate balance of all these components. The aggregate balance of different Bioeconomy components needs a choice of weightings for different Bioeconomy components.

Coelli, et al. (2007) discussed the case when there are two Bioeconomy components, which required two material balance equations. If there are two inputs and one output, the equations are:

$$
\mathrm{z}_{1}=\mathrm{a}_{11} \mathrm{x}_{1}+\mathrm{a}_{21} \mathrm{x}_{2}-\mathrm{b}_{1} q
$$


and

$$
\mathrm{z}_{2}=\mathrm{a}_{12} \mathrm{x}_{1}+\mathrm{a}_{22} \mathrm{x}_{2}-\mathrm{b}_{2} q,
$$

If the chosen weights are $v_{1}$ and $v_{2}$, the aggregate balance equation becomes

$$
\mathrm{v}_{1} \mathrm{z}_{1}+\mathrm{v}_{2} \mathrm{z}_{2}=\left(\mathrm{v}_{1} \mathrm{a}_{11}+\mathrm{v}_{2} \mathrm{a}_{12}\right) \mathrm{x}_{1}+\left(\mathrm{v}_{1} \mathrm{a}_{21}+\mathrm{v}_{2} \mathrm{a}_{22}\right) \mathrm{x}_{2-}\left(\mathrm{v}_{1} \mathrm{~b}_{1}+\mathrm{v}_{2} \mathrm{~b}_{2}\right) q,
$$

and the method proceeds normally.

For example, a national Bioeconomy system uses different types of energetic crops as Soya, Sunflower, Maize, Sugar cane, Wheat, and Yucca in its production. The materials balance equation in (9) can be used to estimate the aggregate balance of materials given a particular choice of weights for the different materials.

The third desirable feature of this approach is that it avoids the potential correlation between the undesirable outputs and conventional inputs in empirical studies. For example, one might want to compare the Bioeconomy performance of agricultural farms which produce biofuels to the environment. The production model can have Bioeconomy as an undesirable output while Biofuels as an input. Statistical data for biofuels is normally estimated by using the formula (biodiesel) $\times$ (biofuels content factor) or (bioethanol) $\times$ (biofuels content factor) Consequently, multicollinearity is a potential problem in this model. This problem, however, is not present in the materials balance condition approach because in(2) there is no undesirable output vector.

Since the surplus balance of fossil fuels causes pollution, some countries (especially OECD member countries) have started regulating the use of biofuels components in Bioeconomy production. One of the most common environmental policies involves the regulation of the limit of emission that the farmer can pollute to the environment (Dowd, et al. 2008; Nam, et al. 2007; Pretty, et al. 2001; Sterner and Köhlin, 2003). Under this regulation, farmers are taxed or levied on the biofuels balance which exceeds a specified limit. One example of this regulation framework is the Mineral Accounting System (MINAS) which monitors the nutrient balance of farms in the Netherlands (Van Der Brandt and Smith 1998).

Under such an environmental regulation system, the farmers operate under a biofuels balance constraint. Applying the biofuels balance condition equation in (1), one can separate two different types of biofuels constraints restricting the behavior of the farmers: (a) given that the output vector is fixed, the limit on the biofuels balance means that the farmers' operation is restricted by the maximum level of biofuels in input and (b) given that the input vector is fixed, the limit on biofuels balance suggests that the farmers are required to achieve the target of minimum total quantity of nutrients in output. These two types of nutrient constraints however can be modeled in a similar manner to the modeling of firms operating under a cost budget restriction and revenue target restriction. Färe and Grosskopf (1994) provide techniques to measure efficiency and productivity performance of the farmers using cost- and revenue in direct technologies. The application of these price-based techniques to biofuels-based problems could be an interesting area of future research. 


\section{Mll Macrothink}

\section{Biofuels-oriented total factor productivity}

In this section, I use the Biofuels-orientated efficiency measure to construct a Biofuels-oriented Total Factor Productivity (BTFP) index. This index builds upon the concept of the input-orientated Malmquist TFP index first proposed by Caves, et al. (1982a; b). The index is constructed by measuring the radial distance of the observed output and input vectors in period $\mathrm{t}$ and $\mathrm{t}+\mathrm{s}$ relative to two reference technologies: technology in period $\mathrm{t}$ and technology in period $\mathrm{t}+\mathrm{s}$.

First, using technology in period $t$ as a reference technology, the Malmquist biofuels-orientated TFP index for period $t$ and $t+s$ is defined as changes in the biofuels-orientated efficiency in period $\mathrm{t}+\mathrm{s}$ over period $\mathrm{t}$ :

$$
M_{i}^{t}=\frac{B E_{i}^{t, t+s}}{B E_{i}^{t, t}}
$$

where the first and second superscripts refer to the reference bio-technology and time period respectively. The subscripts "I" refers to the input-orientation. For example, $B E_{i}^{t, t+s}$ refers to the environmental efficiency score calculated using the observed data for a firm operating in time period $t+s$ relative to the reference biotechnology from time period $t$, using an input-oriented framework.

Similarly, using the biotechnology in period $\mathrm{t}+\mathrm{s}$ as a reference biotechnology, a Malmquist biofuels-orientated TFP index may be defined as:

$$
M_{i}^{t+s}=\frac{B E_{i}^{t+s, t+s}}{B E_{i}^{t+s, t}}
$$

Our BTFP change index (BTFPC) is then defined as the geometric mean of the two previous indices:

$$
B T F P C^{t, t+s}=\llbracket \frac{B E_{i}^{t, t+s}}{B E_{i}^{t, t}} X \frac{B E_{i}^{t+s, t+s}}{B E_{i}^{t+s, t}} \rrbracket^{1 / 2},
$$

All Bes in are defined as follows:

$$
B E_{i}^{t, t}=\frac{a^{\prime} x_{e}^{t^{\prime} t}}{a^{\prime} x^{t, t}}=\frac{a^{\prime} x_{e}^{t, t}}{a^{\prime} x_{t}^{t, t}} X \frac{a^{\prime} x_{t}^{t, t}}{a^{\prime} x^{t, t}}=B A E_{i}^{t, t} x T E_{i}^{t, t}
$$

$B E_{i}^{t, t}$ can be estimated in a biofuels input-oriented framework (e.g. by a cost-minimizing DEA) and $T E_{i}^{t, t}$ is estimated in a standards input-oriented framework given a input vetor $x^{t, t}$ of time t corresponding to a specified output level of $q^{t}$ at time t. 


$$
B E_{i}^{t+s, t+s}=\frac{a^{\prime} x_{e}^{t+s, t+s}}{a^{\prime} x^{t+s, t+s}}=\frac{a^{\prime} x_{e}^{t+s, t+s}}{a^{\prime} x_{t}^{t+s, t+s}} X \frac{a^{\prime} x_{t}^{t+s, t+s}}{a^{\prime} x^{t+s, t+s}}=B A E_{i}^{t+s, t+s} \times T E_{i}^{t+s, t+s}
$$

$B E_{i}^{t+s, t+s}$ is estimated in a biofuels input -oriented framework and $T E_{i}^{t+s, t+s}$ is estimated in a standard input-oriented framework given a input vector $x^{t+s, t+s}$ at time corresponding a specified output level of $q^{t+s}$ at time $\mathrm{t}+\mathrm{s}$.

$$
B E_{i}^{t, t+s}=\frac{a^{\prime} x_{e}^{t, t+s}}{a^{\prime} x^{t, t+s}}=\frac{a^{\prime} x_{e}^{t, t+s}}{a^{\prime} x_{t}^{t, t+s}} X \frac{a^{\prime} x_{t}^{t, t+s}}{a^{\prime} x^{t, t+s}}=B A E_{i}^{t, t+s} \times T E_{i}^{t, t+s},
$$

$B E_{i}^{t, t+s}$ is estimated in a biofuels input-oriented framework and $T E_{i}^{t, t+s}$ is estimated in a standard input-oriented framework given a input vector $x^{t, t+s}$ of time $\mathrm{t}+\mathrm{s}$ corresponding a specified output level of $q^{t}$ at time t.

$$
B E_{i}^{t, t, s}=\frac{a^{\prime} x_{e}^{t, t, s}}{a^{\prime} x^{t, t, s}}=\frac{a^{\prime} x_{e}^{t, t, s}}{a^{\prime} x_{t}^{t, t, s}} X \frac{a^{\prime} x_{t}^{t, t, s}}{a^{\prime} x^{t, t, s}}=B A E_{i}^{t, t, s} x T E_{i}^{t, t, s},
$$

$B E_{i}^{t, t, s}$ is estimated in a biofuels input-orientated framework and $T E_{i}^{t, t, s}$ is estimated in a standard input-oriented framework given a input vector $a^{\prime} x^{t, t, s}$ of time $\mathrm{t}$ corresponding a specified output level of $q^{t+s}$ at time $\mathrm{t}+\mathrm{s}$.

Following Caves, et al. (1982a;b), the standard input oriented Malmquist YFP index is defined as

$$
T F P C_{i}=\llbracket \frac{T E_{i}^{t, t+s}}{T E_{i}^{t, t}} X \frac{T E_{i}^{t+s, t+s}}{T E_{i}^{t+s, t}} \rrbracket^{1 / 2}
$$

which can be decomposed into

$$
T F P C_{i}=\frac{T E_{i}^{t+s, t+s}}{T E_{i}^{t, t}} \llbracket \frac{T E_{i}^{t, t}}{T E_{i}^{t+s, t}} X \frac{T E_{i}^{t, t+s}}{T E_{i}^{t+s,+s, t}} \rrbracket^{1 / 2}=T E C_{i} x T C_{i}
$$

where $T E C_{i}$ is technical efficiency change and $T C_{i}$ is the geometric mean of two technical change indices, evaluated at the period $t$ and period $t+s$ data points, respectively.

Thus, using equations 10 to 18 , we have

$$
B T F P C_{i}=T F P C_{i} x \llbracket \frac{B T E_{i}^{t, t+s}}{B T E_{i}^{t, t}} X \frac{B T E_{i}^{t+s, t+s}}{B T E_{i}^{t+s, t}} \rrbracket^{1 / 2},
$$

and hence 


$$
\mathrm{BTFPC}_{i}=T E C_{i} \times T C_{i} \llbracket \frac{B T E_{i}^{t, t+s}}{B T E_{i}^{t, t}} \times \frac{B T E_{i}^{t+s, t+s}}{B T E_{i}^{t+s, t}} \rrbracket^{1 / 2}=T E C_{i} \times T C_{i} \times B A E C_{i}
$$

Technical efficiency change (TEC) refers to changes in technical efficiency of the observed unit against the technically efficiency unit, technical change (TC) refers to the shift of the technically efficient frontier, and biofuels-oriented allocative efficiency change (BAEC)) measures the effect of allocative decisions on environmental performance.

\section{The Bioeconomy In Central America Application}

On 19-20 September 2011, in Cali Colombia was developed the LAC regional IAAE Inter-conference Symposium on the Bio-economy.The theme was "The Bioeconomy in Latin America and the Caribbean: Towards a socioeconomic research agenda”. The objective was promote a discussion concept note bioeconomy about, introduce the bioeconomy concept, its drivers, and main areas of work and impact to help identify the themes were more socioeconomic analysis is needed in order, for society in general and policy makers in particular, to better understand and steer the emerging bioeconomy in the specific context of the Latin American and the Caribbean countries (Trigo, 2011).

One of the main points of discussion in this symposium relates to the estimation of productivity growth is demanded. Current productivity levels are getting dangerously close to genetic ceiling, water scarcity is a growing problem in many regions, where competition between residential and agricultural land use is becoming a more scenario. Between the types of socioeconomic research needed to mobilize / back-up public and private decision making regarding bioeconomy development in LAC are identifying and estimating the potential bioeconomy benefits for LAC countries: macroeconomic impacts, trade implications, impact on employment of bioeconomy alternatives, food security implication, analysis of impact of specific bioeconomy components/issues(land use, alternative feedstock, biofuels, bio refineries, bio-based value-chains) on food security, climate change, rural development, employment.

The Bioeconomy of national agricultural production system Figures 2 and 3 provide a diagrammatical representation of the key energetic crops and the flow of the biofuels in a Central American agricultural production system. Those figures are extracted from Garcia (2006) which is a modified version of the farm gate method of accounting for biodiesel and bioethanol flows.

The agricultural production of a Central American country is considered to be a "black box" in which there is an interaction of livestock and crop production activities. In the production system, harvested fodder crops and grazed grass are consumed be the livestock and the excretion of the livestock is a source of biofuels. In Central America ${ }^{2}$ there are 13 crops which contribute to obtain the biofuels. Both for Bioethanol are sugar cane, maize, sugar beet, sorgo, yucca and sorghum and for Biodiesel are palm, soybean, sunflower, castor, cotton, and rapeseed and jatrophacurcas.

\footnotetext{
${ }^{2}$ Estudio exploratorio No PSA 028/07 Insumos para la producción de biocombustibles. Innovaciones Tecnológicas. Ing. Agr. DELAFOSSE, Roberto Mario. INTEA S.A, Dr. Medina, Juan Jorge . IES-INTA.
} 


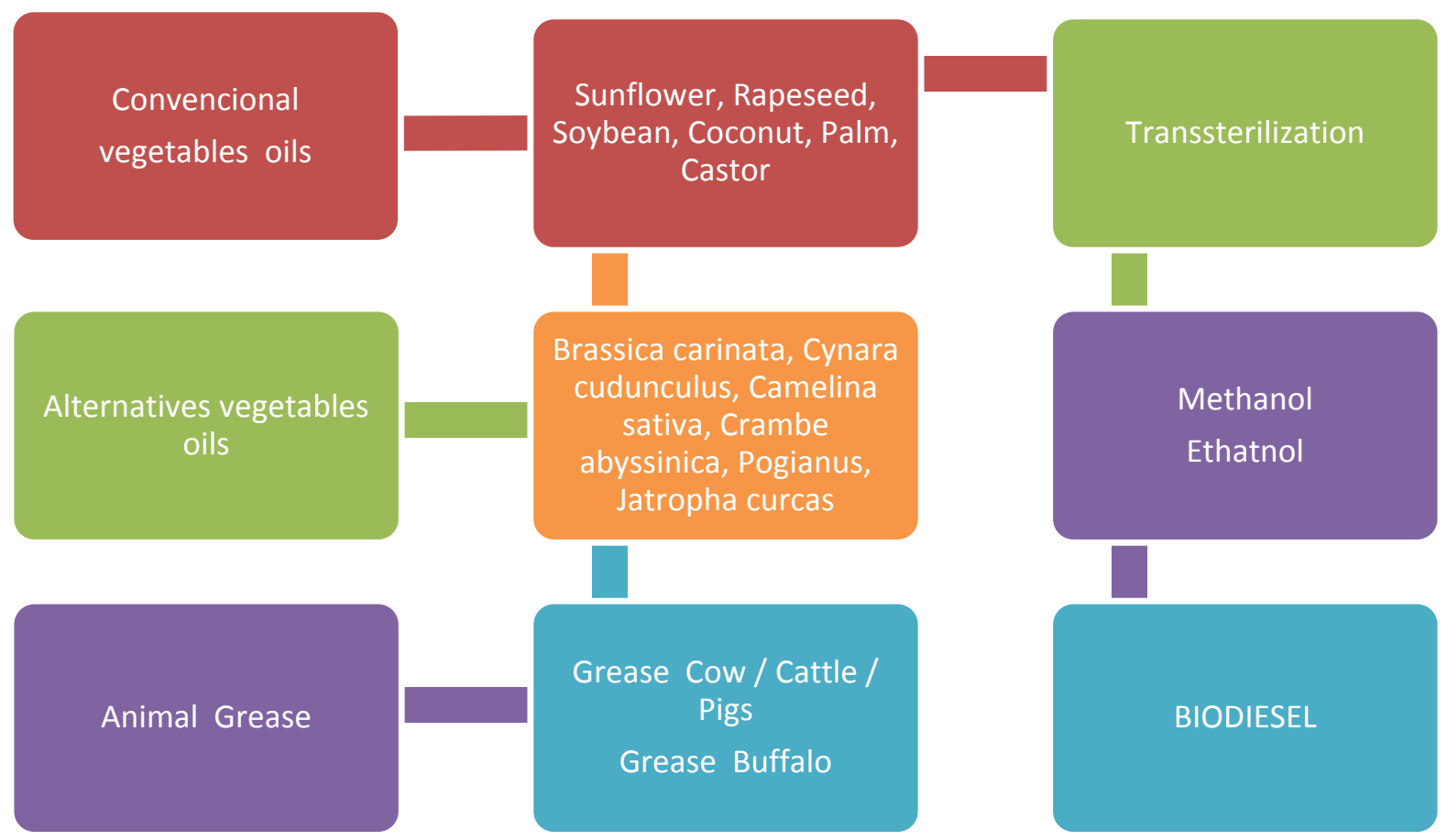

Figure 2. Energetic Crops used in Biodiesel Production Process

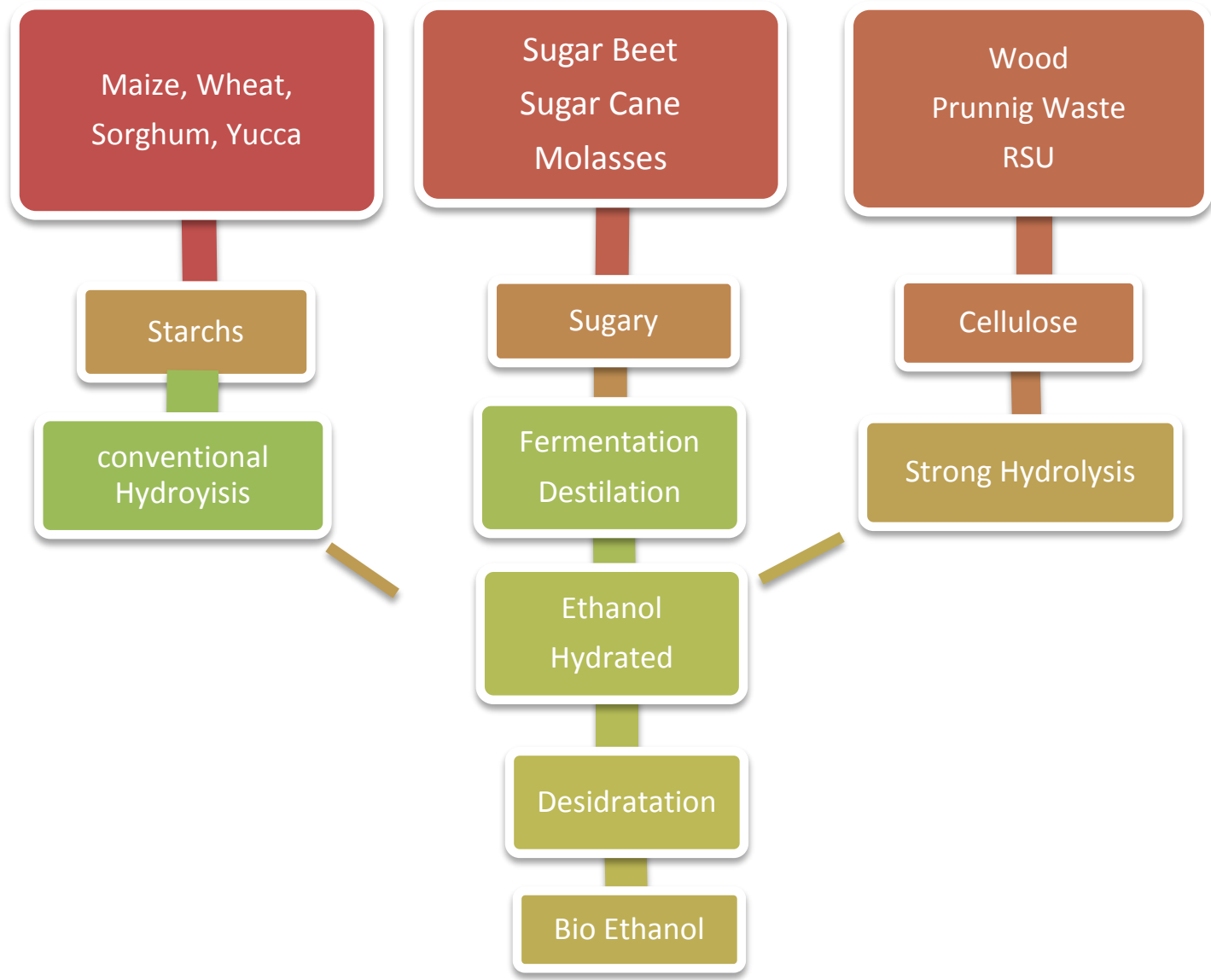

Figure 3. Energetic Crops used in Bioethanol Production Process 


\section{DEA Methodology for Bio Economy}

In this paper I measure bio economy total factor productivity TFP using the Malmquist index methods described in Färe et al (1994) and Coelli, Rao and Battese (1998, Ch. 10). This approach uses data envelopment analysis (DEA) methods to construct a piece-wise linear production frontier for each year in the sample where bio ethanol is included. I firstly provide a brief description of DEA methods before we go on to describe the Malmquist TFP calculations.

\section{Data Envelopment Analysis (DEA)}

DEA is a linear-programming methodology, which uses data on the input where the output quantities of a group of countries to construct a piece-wise linear surface over the data points.

This frontier surface is constructed by the solution of a sequence of linear programming problems - one for each country in the sample. The degree of technical inefficiency of each country (the distance between the observed data point and the frontier) is produced as a byproduct of the frontier construction method.

DEA can be either input-orientated or output-orientated. In the input-orientated case, the DEA method defines the frontier by seeking the maximum possible proportional reduction in input usage, with output levels held constant, for each country. While, in the output-orientated case, the DEA method seeks the maximum proportional increase in output production, with input levels held fixed. The two measures provide the same technical efficiency scores when a constant return to scale (CRS) technology applies, but are unequal when variable returns to scale (VRS) is assumed. In this paper we assume a CRS technology (the reasons for this are outlined in the Malmquist discussion below). Hence the choice of orientation is not a big issue in our case. However, I have selected an output orientation because we believe it would be fair to assume that, in agriculture, one usually attempts to maximize output from a given set of inputs, rather than the converse.

I provide a brief description of DEA in a constant returns to scale (CRS) model where there is data on $\mathrm{K}$ inputs (denoted by an input vector $\mathrm{x}$ ) and $\mathrm{M}$ outputs (denoted by an output vector $\mathrm{q}$ ) on each of $\mathrm{N}$ firms or decision making units (DMUs). For the i-th DMU these are represented by the vectors $\mathrm{xi}$ and qi, respectively. The $\mathrm{KxN}$ input matrix, $\mathrm{X}$, and the $\mathrm{MxN}$ output matrix, $\mathrm{Y}$, represent the data of all $\mathrm{N}$ DMUs. The purpose of DEA is to construct a non-parametric envelopment frontier over the data points such that all observed points lie on or below the production frontier.

For each DMU we would like to obtain a measure of the ratio of all outputs over all inputs, such as u'qi/v'xi, where $u$ is an Mx1 vector of output weights and $v$ is a $\mathrm{Kx} 1$ vector of input weights.

To select optimal weights we can specify the mathematical programming problem:

$$
\max _{u, v}\left(\frac{u^{\prime} q_{i}}{v^{\prime} x_{i}},\right.
$$




$$
\begin{aligned}
& \text { st }-\frac{u^{\prime} q_{i}}{v^{\prime} x_{i}} \leq 1, j=1,2,3, \ldots \ldots \ldots \ldots, N, \\
& u, v \geq 0
\end{aligned}
$$

where

$y_{i}$ is a $\mathrm{Mx} 1$ vector of output quantities for the $i$-th Central American country;

$x_{i}$ is a $\mathrm{K} \mathrm{x} 1$ vector of input quantities for the $i$-th Central American country;

$\mathrm{Y}$ is a N x M matrix of output quantities for all N Central American countries;

$\mathrm{X}$ is a $\mathrm{N} \mathrm{x} \mathrm{K} \mathrm{matrix} \mathrm{of} \mathrm{input} \mathrm{quantities} \mathrm{for} \mathrm{all} \mathrm{N} \mathrm{Central} \mathrm{American} \mathrm{countries;}$

$\lambda$ is a $\mathrm{N} x 1$ vector of weights; and

$\phi$ is a scalar.

Observe that $\phi$ will take a value greater than or equal to one, and that $\phi-1$ is the proportional increase in outputs that could be achieved by the $i$-th country, with input quantities held constant. Note also that $1 / \phi$ defines a technical efficiency (TE) score which varies between zero and one (and that this is the output-orientated TE score reported in our results).

The above LP is solved N times - once for each country in the sample. Each LP produces a $\phi$ and a $\lambda$ vector. The $\phi$-parameter provide information on the technical efficiency score for the $i$-th country and the $\lambda$ - vector provides information on the peers of the (inefficient) $i$-th country. The peers of the $i$-th country are those efficient countries that define the facet of the frontier against which the (inefficient) $i$-th country is projected.

The DEA problem can be illustrated using a simple example for Bio Economy. Consider the case where we have a group of five Central American countries producing one output (e.g., sugar cane and sugar beet). Assume for simplicity that each country has identical input vectors. These five countries are depicted in Figure 3. Countries A, B and C are efficient countries because they define the frontier. Countries D and E are inefficient countries. For country $\mathrm{D}$ the technical efficiency score is equal to

$$
T E_{D}=\frac{0 D}{0 D^{\prime}}
$$

and its peers are countries A and B. In the DEA output listing this country would have a technical efficiency score of approximately 70 percent and would have non-zero $\lambda$-weights associated with countries A and B. For country E the technical efficiency score is equal to

$$
T E_{E}=\frac{0 E}{0 E^{\prime}}
$$

and its peers are countries B and C. In the DEA output listing this country would have a technical efficiency score of approximately 50 percent and would have non-zero $\lambda$-weights associated with countries B and C. Note that the DEA output listing for countries A, B and C 


\section{Macrothink}

would provide technical efficiency scores equal to one and each country would be its own peer. For further discussion of DEA methods see Coelli, Rao and Battese (1998, Ch. 6).

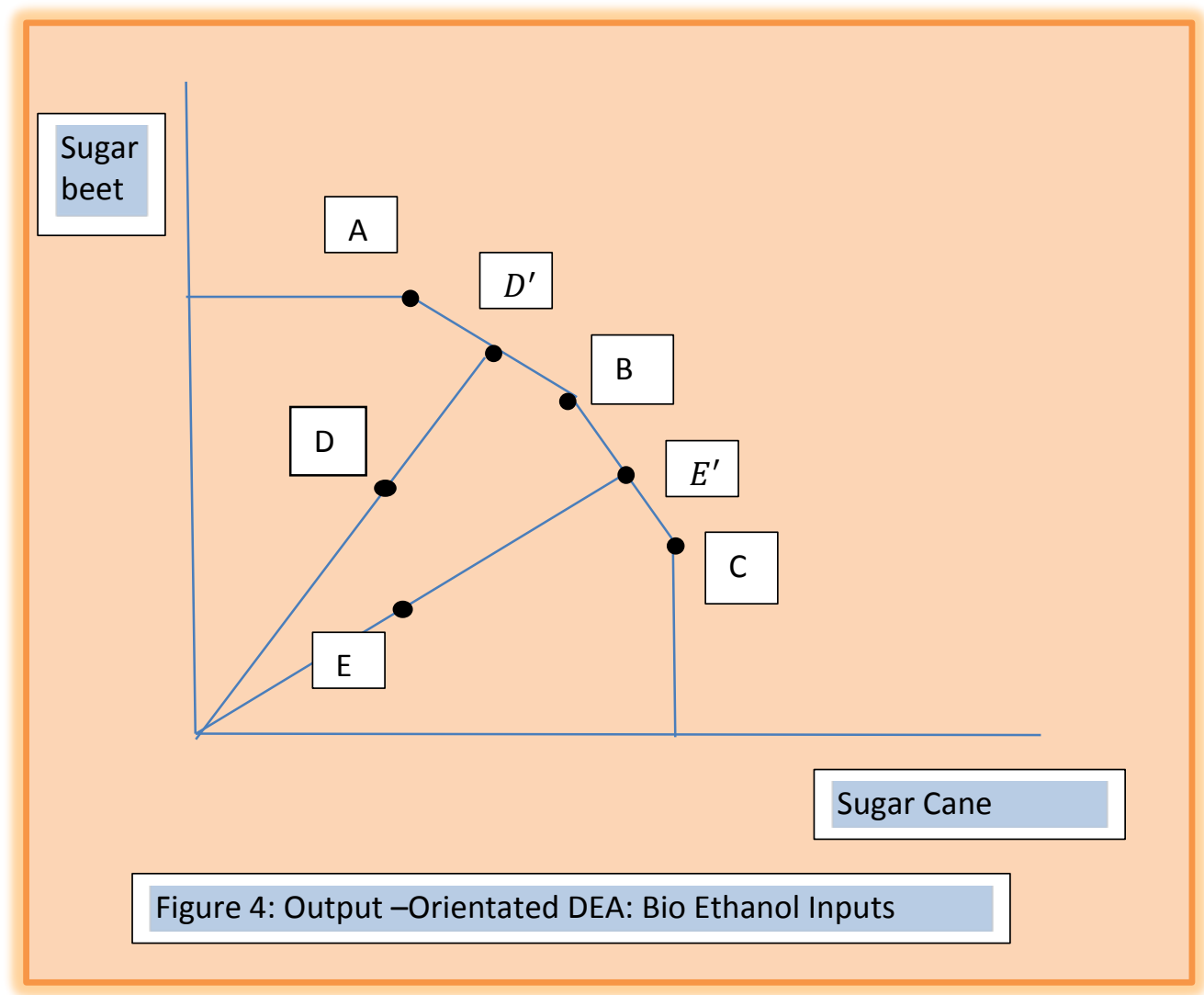

(Transfer the figure to JGP format and Insert it here)

Figure 4. Output -Orientated DEA: Bio Ethanol Inputs

\section{The Malmquist TFP Index for Bio Economy}

The Malmquist index is defined using distance functions. Distance functions allow one to describe a multi-input, multi-output production biotechnology without the need to specify a behavioral objective (such as cost minimization or profit maximization). One may define input distance functions and output distance functions. An input distance function characterizes the production technology by looking at a minimal proportional contraction of the input vector, given an output vector. An output distance function considers a maximal proportional expansion of the output vector, given an input vector. We only consider an output distance function in detail in this paper. However, input distance functions can be defined and used in a similar manner.

I first define some notation. Consider the situation where there is a firm (Country) that produces a vector of $\mathrm{m}=1,2,3, \ldots \mathrm{M}$ outputs, $\mathrm{q} \in \Psi^{M}$, using a vector $\mathrm{k}$ of $1,2,3, \ldots \mathrm{K}$ input, $\mathrm{x} \in \Psi^{K}$. The production activity also produces bio economy components as bio-fuels products. The amount of bio economy is defined by the bio economy components condition 


$$
z=a x-b q
$$

where a and b are vectors of known non-negative constants. Following Coelli, et al. (2007), I allow the possibility that some of inputs could have zero amounts of the bioeconomy component concern, for example biodiesel and bioethanol.

A production bio technology may be defined using the output set, $\mathrm{P}(\mathrm{x})$, which represents the set of all output vectors, $y(q, u)$, which can be produced using the input vector, $\mathrm{x}$.

Chung, et al. (1997) define the production technology by the output set in which input vector $\mathrm{x}$ is used to produce good output $\mathrm{q}$ and undesirable output $\mathrm{u}$ :

$$
\mathrm{P}(\mathrm{x})=\{(\mathrm{q}, \mathrm{u}): \mathrm{x} \text { can produce }(\mathrm{q}, \mathrm{u})\}
$$

It assumes that the technology satisfies the axioms listed in Coelli, Rao and Battese (1998,Ch. 3)

The output distance function is defined on the output set, $\mathrm{P}(\mathrm{x})$, as:

$$
d_{0}(x, y)=\min \left\{\delta:\left(\frac{y}{\delta}\right) \epsilon P(x)\right\}
$$

The distance function, do(x,y), will take a value which is less than or equal to one if the output vector, $\mathrm{y}$, is an element of the feasible production set, $\mathrm{P}(\mathrm{x})$. Furthermore, the distance function will take a value of unity if $y$ is located on the outer boundary of the feasible production set, and will take a value greater than one if $y$ is located outside the feasible production set. In this study we use DEA-like methods to calculate our distance measures.

These are discussed shortly.

The Malmquist TFP index measures the TFP change between two data points (e.g., those of a particular country in two adjacent time periods) by calculating the ratio of the distances of each data point relative to a common technology. Following Färe et al (1994), the Malmquist (output-orientated) TFP change index between periods (the base period) and period $t$ is given by

$$
\mathrm{D}(\mathrm{x}, \mathrm{q}, \mathrm{u}, \mathrm{g})=\sup \{\beta:(\mathrm{q}, \mathrm{u})+\beta \mathrm{g} \in \mathrm{P}(\mathrm{x})\}
$$

where $g$ is the vector of directions in which good output is increased and undesirable output is decreased.

The directional distance function of Chung, et al. (1997) is illustrated in Figure 1, where we depict the simple case of one desirable output and one undesirable output. The production frontier is defined by the line $0 \mathrm{Y}$, which corresponds to a particular quantity of input. The direction vector $g=(-\mathrm{u}, \mathrm{q})$ is used to project point A (the observed data point for firm A) to point $B$ (which is technically efficient). This involves expanding the desirable output (q) and contracting undesirable output (u).

From the diagram, it can be shown that $\left(q_{2} / q_{1}-\beta\right.$ and hence $\left.u_{2} / u_{1}-2-\beta\right)$ 


\section{Il Macrothink}

Journal of Agricultural Studies

ISSN 2166-0379

2013, Vol. 1, No. 1

The materials balance condition applied in this model indicates that at points A and B, respectively, we have ${ }^{3}$

$$
u=a x-b \beta q
$$

and

$$
(2-\beta) u=a x-b \beta q
$$

Then combining (28) y (29) we obtain

$$
(a x-2 b q)(\beta-1)=0
$$

Equation (30) has two solutions: $\beta=1$ and $a x=2 b q$. The first solution $(\beta=1)$ means that only efficient firms satisfy both the directional distance function measure and the materials balance condition (i.e. any interior point in the production technology such as point A in Figure 1 is not feasible). The second solution indicates that the amount of nutrient in the input vector must always be exactly equal to double the amount in the output vector. Neither of these solutions are a desirable feature of a directional distance function.

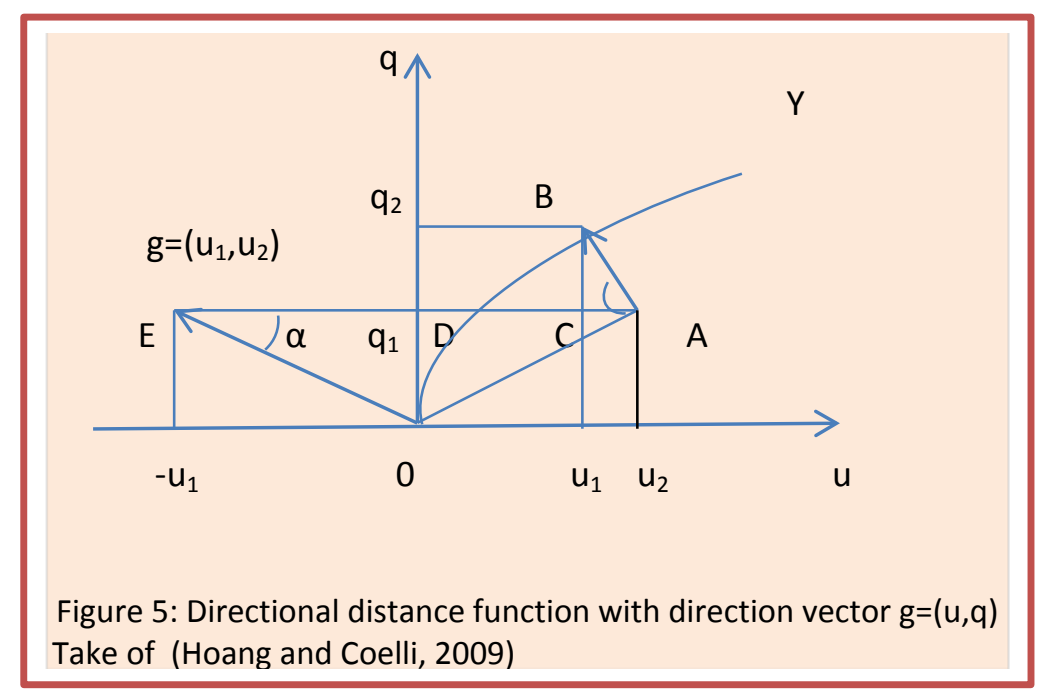

\section{Data}

The present study is based on data exclusively drawn from the AGROSTAT system of the Statistics Division of the Food and Agricultural Organization in Rome. I have been able to access and down-load all the necessary data from the Web site of the $\mathrm{FAO}^{4}$. The following are some of the main feature of the data series used.

The empirical analysis in this paper involved annual data on 7 Central American countries during the period 1980-2007. The biofuels are consider in the agricultural system in our

\footnotetext{
${ }^{3}$ Note that $\mathrm{z}=\mathrm{u}$ in this case.

4 This data are availability on http://faostat.fao.org/
} 
analysis because is important data and their significant contribution in the balance Bio Economy.

Country coverage: The study includes 7 Central American countries: These are the top 7 agricultural producer of the Central America, which produce cropoils for Biodiesel as Soyabean oil, Coconut oil, Cottonseed oil, Palm oil, Sunflower seed oil as well as Bio Ethanol as such Maize, Wheat, Sorghum, Sugar cane, Sugar beet. The countries included in the study are: Belize, Guatemala, Honduras, El Salvador, Nicaragua, Costa Rica, and Panamá.

Time period: The present paper is based on results for the period 1980 to 2007 (27 observations).

Output Series: Due to the problems of degree of freedom associated with the application of DEA methods, the present study uses one output crops variables. The output series for this variable is derived by aggregating detailed output quantity data on 56 agricultural commodities.

The output aggregate were constructed using international average price expressed in US dollars. The output series for the period studied are at constant prices ${ }^{5}$ and expressed in a single currency unit. The years 2004-2006 output series were extended to cover the study period 1980-2007 using the FAO production index number series for crops.

The current value of production measures value in the prices relating to the period being measured. Thus, it represents the market value of food and agricultural products at the time they were produced. Value of production in constant terms is derived using the average prices of a selected year or years, known as the base period.

Another point regarding the output series that is important to remember is the fact the output series are based on 2004-2006 international average prices.

Input Series: Given the constraints on the number of input variables that could be used in the DEA Analysis, we have opted to consider only four inputs variables. Details of these variables are given below:

Land: This variable covers the arable land, land under permanent crops as well as the area under permanent pasture. Land under permanent crops is the land cultivated with crops that occupy the land for long periods and need not be replanted after each harvest. This category includes land under flowering shrubs, fruit trees, nut trees and vines but excludes land under trees grown for wood or timber. Land under permanent pasture is the land used permanently (five years or more) for forage crops, either cultivated or growing wild.

\footnotetext{
${ }^{5}$ Value of gross production has been compiled by multiplying gross production in physical terms by output prices at farm gate. Thus, value of production measures production in monetary terms at the farm gate level. Since intermediate uses within the agricultural sector (seed and feed) have not been subtracted from production data, this value of production aggregate refers to the notion of "gross production".
} 


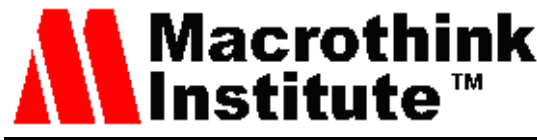

Tractor: This variable covers the total number of wheel and crawler tractors imported, but excluding garden tractors, used in agriculture. It is important to note that only the number of tractors imported is used as the input variable.

Labour: This variable refers to economically active population in agriculture. Economically active population is defined as all persons engaged or seeking employment in an economic activity, whether as employers, own-account workers, salaried employees or unpaid workers assisting in the operation of a family farm or business. Economically active population in agriculture includes all economically active persons engaged in agriculture, forestry, hunting or fishing. This variable obviously overstates the labour input used in agricultural production the extent of overstatement depends upon the level of development of the country.

Bioethanol: This variable assumption that countries studied produce biodiesel. For this, I calculate by transform crops to bioethanol as they are drawn from conversion tables in (Coviello, 2005). The energetic crops (i.e. crops exported) used in Bio Ethanol production system were Maize, Wheat, Sorghum, Sugar cane, Sugar beet, Molasses and Yucca. This variable is used for developing a new measure of total factor productivity growth in agricultural.

Fertilizer: This variable refers the quantity total of fertilizer used for each country. These fertilizers are Nitrogen ( $\mathrm{N}$ total nutrients), Phosphate (P205 total nutrients), and Potash Fertilizers (K20 total nutrients). This variable is expressed in Consumption in nutrients measured on tones.

\section{Results and Discussion}

The results of DEA and BTFP calculations are summarized in this section. Given that I have 27 annual observations on 7 Central American countries, I have a lot of computer output to describe.

The calculation involved the solving of $(7 \times(3 \times 27-2))=$ LP 553 problems ${ }^{6}$. It has hundreds of pieces of information on the efficiency scores and peers of each country in each year. It also has measures of Bio Economy technical efficiency change, Bio Economy technical change and Bio Economy TFP change for each country in each pair of adjacent year.

Hence I have tried to be careful in like results are presenting in this paper where the component of Bio Economy is included. Information on the means of the measure of Bio Economy efficiency change, Bio Economy technical change and Bio Economy TFP change is provided for each Central American country over the 27 year period and the mean changes between each pair of adjacent year over the 7 countries. I also provide a table of peer for all Central American countries in the first year (1980) and in the final year (2007).

Averages of bio economy technical efficiency score in 1980 and 2007 are reported in table 1 where I assume the production of bio ethanol as key input for seven countries and the full sample. Note that the average bio economy technical efficiency score of 1.126 in 1980

\footnotetext{
${ }^{6}$ If you have T time periods, you must calculate (3T-2) LP's for each country in the sample. Hence, if you have N countries, you will need calculate Nx(3T-2) LP’s (Coelli, 1994)
} 
implies that if those Central American countries were producing bioethanol then they were producing 13 percent of the output that could be potentially the production using the observed input quantities (bio ethanol). It is interesting to note that those Central American countries with the lowest mean biotechnical efficiency scores in 1980 were - Nicaragua, El Salvador and Guatemala- however also achieved the largest increase in mean bio technical efficiency over the sample period. This provides evidence of catch-up in these Central American countries, which was not found in many of the studies listed on in table 0 . This is most likely due to the fact that our data set spans the past three decade where the bio Ethanol input is considered, while the majority of these studies consider the 1960-2007 period and they don't considered the bio ethanol as key input.

\begin{tabular}{|c|c|c|c|}
\hline \multicolumn{4}{|c|}{ Analyses of inter-country agricultural total factor productivity (TFP) growth, 1993-2011 } \\
\hline Authors & Method & Years & Countries \\
\hline Fulginiti and Perrin (1993) & $\mathrm{CD}$ & $1961-85$ & 18 LDC \\
\hline Bureau et al. (1995) & DEA \& Fisher & 1973-89 & $10 \mathrm{DC}$ \\
\hline Fulginiti and Perrin (1995) & DEA & $1961-85$ & 18 LDC \\
\hline Craig et al(1997) & $C D$ & $1961-90$ & 98 \\
\hline Lusigi and Thirtle (1997) & DEA & 1961-91 & 47 Africa \\
\hline Fulginiti and Perrin (1998) & $\mathrm{CD}(\mathrm{VC})$ & $1961-85$ & 18 LDC \\
\hline Rao and Coelli (1998) & DEA & $1961-95$ & 97 \\
\hline Amade (1998) & DEA & $1961-93$ & 70 \\
\hline Fulginiti and Perrin (1999) & DEA \& CD & 1961-85 & 18 LDC \\
\hline Martin and Mitra (1999) & Translog & 1967-92 & 49 \\
\hline Wiebe et al. (2000) & $\mathrm{CD}$ & $1961-97$ & 110 \\
\hline Chavas (2001) & DEA & $1960-95$ & 12 \\
\hline Ball et al. (2001) & Fisher (EKS) & $1973-93$ & $10 \mathrm{DC}$ \\
\hline Suhariyanto et al. (2001) & DEA & $1961-96$ & 65 Asia/Africa \\
\hline Suhariyanto and Thirtle (2001) & DEA & $1961-96$ & 65 Asia \\
\hline Trueblood and Coggins (2003) & DEA & $1961-91$ & 115 \\
\hline Nin et al (2003) & DEA & $1961-94$ & 20 LDC \\
\hline Rao and O'Donnell(2004) & DEA-SFA MF & $1986-90$ & 97 \\
\hline Coelli and Rao (2005) & DEA & $1980-00$ & 93 \\
\hline Coelli et al (2005) & DEA & 1987-02 & 100 Belgium farms \\
\hline Tong et al (2009) & DEA-SFA & 1994-05 & 29 Chinise provinces \\
\hline Hoang and Coelli (2009) & DEA & $1990-03$ & 28 OECD \\
\hline Yeboah et al (2011) & DEA & $1980-07$ & $3 \mathrm{DC}$ \\
\hline
\end{tabular}

Table 1 : Mean of Bio Economy Technical Efficiency for Countries, 1980-2006

\begin{tabular}{lrrr}
\hline \hline Countries & 1980 & 1990 & 2006 \\
Belize & 1.141 & 1.106 & 1.403 \\
Costa Rica & 1.304 & 1.107 & 3.881 \\
El Salvador & 1.053 & 1.811 & 0.998 \\
Guatemala & 1.03 & 1.898 & 0.813 \\
Honduras & 1.192 & 4.052 & 1.424 \\
Nicaragua & 0.526 & 1.618 & 1.961 \\
Panamá & 1.638 & 1.423 & 0.994 \\
Mean Central America mean & 1.126 & 1.859 & 1.639 \\
\hline \hline
\end{tabular}

The information on changes of averages biotechnical efficiency only tells the "catch-up" as part of the productivity story. The hypothetic case is at what times these countries produce bio ethanol instead export it. BTFP change can also appear in the form of technical change 
(or frontier-shift). The means of the measures of technical efficiency change, technical change and TFP change for each country (over the 27-year sample period) are presented in Table 2. Table 4 shows the weighted annual averages (averaged over the 7 countries) of bio economy efficiency change, bio economy technical change and BTFP change.

\begin{tabular}{|c|c|c|c|c|}
\hline No & Country & btfpch & beffch & btechch \\
\hline 1 & Belize & 1.044 & 1 & 1.044 \\
\hline 4 & Guatemala & 1.036 & 1 & 1.036 \\
\hline 6 & Nicaragua & 1.033 & 1.018 & 1.014 \\
\hline 3 & El Salvador & 1.009 & 1 & 1.009 \\
\hline 7 & Panamá & 0.997 & 1 & 0.997 \\
\hline 2 & Costa Rica & 0.984 & 1 & 0.984 \\
\hline \multirow[t]{2}{*}{5} & Honduras & 0.979 & 1 & 0.979 \\
\hline & Central America (mean) & 1.011 & 1.003 & 1.009 \\
\hline
\end{tabular}

Table 2 shows the mean bio economy technical efficiency change, bio economy technical change and BTFP change for the 7 countries over the period 1980 to 2007. Countries in the table are presented in descending order for magnitude of the BTFP changes. The table shows Belize and Guatemala, Nicaragua like the three countries with maximum BTFP growth. Belize shows a 4.4 percent average growth in BTFP, which is due to 4.4 percent growth in bio economy technical efficiency, and keeping growth in bio economy technical change. Guatemala and Nicaragua respectively exhibit BTFP growth rates of 3.6 and 1.4 percent. The unweighted average (across all countries) growth in BTFP is 1.1 percent.

In Table 3 we can identify all those countries that define the frontier bio economy technology for the years 1980 and 2007 in the vicinity of their observed output and input mixes. The table shows that there are 3 countries that are on the frontier in 1980, however in 2007 here aren't change in all countries. Only 3 countries, Belize, Costa Rica, and Panamá, which were on the frontier in 1980, were no longer in the frontier in 2000. Table 3 also provides a list of countries that define the best practice (peers) for each of the countries that are not on the frontier. It is interesting to observe the changes in the sets of peer countries over the two periods. For example, in 1980 Belize and Costa Rica had Nicaragua as its peers. However, in 2000 any country remained in the peer country set.

The last two columns of Table 3 show the number of times each of the efficient countries on the frontier appear as a peer for the bio economy technically inefficient countries. Countries that do not appear as a peer for any other country may be considered to be on the frontier due to the unique nature of their input and output mix. For example El Salvador, Guatemala, Honduras y Nicaragua does not appear as a peer for any country in 1980. In contrast, Belize, Costa Rica and Panamá appear as a peer for 1 country in 1980. 
Tabla 3: Peer from DEA, 1980 and 2007

\begin{tabular}{|c|c|c|c|c|c|c|}
\hline \multirow[b]{2}{*}{ Country } & \multicolumn{4}{|c|}{ Peer } & \multicolumn{2}{|c|}{ Conteo* } \\
\hline & & 980 & & & & \\
\hline 1 Belize & 1 & & & 1 & 1 & 0 \\
\hline 2 Costa Rica & 2 & & & 2 & 1 & 0 \\
\hline 3 El Salvador & 3 & & & 3 & 0 & 0 \\
\hline 4 Guatemala & 4 & & & 4 & 0 & 0 \\
\hline 5 Honduras & 5 & & & 5 & 0 & 0 \\
\hline 6 Nicaragua & 7 & 1 & 2 & 6 & 0 & 0 \\
\hline 7|Panama & 7 & & & 7 & 1 & 0 \\
\hline
\end{tabular}

Table 4 shows the annual average bio economy technical efficiency change, bio economy technical change and BTFP change. This table shows the effect of the annual averages derived. Averages show only 0.09 percent growths in BTFP. This information also is showed in Figure 6 shows BTFP indices from 1980 to 2007 for the different Central American countries.

\section{Conclusions}

This paper presents some important findings on level and trends of productivity Bio Economy in Central America over the past three decades. In the results presented here it examine the growth in Bio Economy productivity in 7 countries over the period 1980 to 2007. The results show an annual growth from bio economy total factor productivity of 1.1 percent, explained by 0.03 percent per year of the bio economy efficiency change (or bio economy catch-up) and bio economy technical change (or bio ethanol frontier-shift) providing 0.09 percent. There is little evidence of the technology regression discussed in a number of the papers listed in Table 0 . This is most likely a consequence of the use of a different sample period that stretched out to groups of countries and the introduction the knowledge based on bio economy (KBBE) with the bio ethanol as input. In terms of individual country performance, the most extraordinary performance is posted by Belize with an average annual growth of 4 percent in BTFP over the study period. Other countries with an average with strong performance are Guatemala and Nicaragua.

Though the results are quite reasonable and meaningful, this situation is a hypothetic case where the vegetables exports and oil exports were transforming to bio ethanol, I am quite conscious of the data limitation and the need for further work in this area of knowledge based on bio economy. For future works we should include: a) an examination of the robustness of the results of the results to shift in the base period for the computation of output aggregate; $b$ ) the inclusion of biodiesel, bioethanol inputs set; c) an investigation of the effects of the investment for bio economy; d) utilization of parametric distance functions to study the robustness of the findings to the choice of methodology based on bio economy. 


\section{Acknowledgement}

The research was financed by International Association of Agricultural Economist. I would like to recognize to the Autonomous National University of Nicaragua, León for your contribution to this researching.

\section{References}

Arnade, C. (1998). "Using a Programming Approach to Measure International Agricultural Efficiency and Productivity”, Journal of Agricultural Economics, 49, 67-84.

Avila, A.F.D., \& R.E. Evenson. (1995). “Total Factor Productivity Growth in Brazilian Agriculture and the Role of Agricultural Research.”Anais do XXXIII Congresso Brasileiro de Economia e Sociologia Rural. Volume 1: 631-657.

Ball, V. Eldon, C.A. Knox Lovell, Richard Nehring, \& Agapi Somwaru.(1994) "Incorporating Undesirable Outputs into Models of Production." Cahiers d'economieet Sociologie 31(1994):60-74.

Ball, V. Eldon, Bureau, J.C., Butault, J.P., \& Nehring, R. (2001). "Levels of Farm Sector Productivity: An International Comparison”, Journal of Productivity Analysis, 15, 5-29.

Baker, Mindy L., Hayes, Dermot J., Babcock, \& Bruce A. (2008). “Crop-Based Biofuel Production under Acreage Constraints and Uncertainty”, Working Paper 08 WP 460. Center for Agricultural and Rural Development.Iowa State University. Ames, Iowa 50011-1070. www.card.iastate.edu

Bureau, C., R. Färe \& S. Grosskopf.(1995). “A Comparison of Three Nonparametric Measures of Productivity Growth in European and United States Agriculture”, Journal of Agricultural Economics, 46, 309-326.

Caves, D. W., L. R. Christensen, \& W. E. Diewert, (1982a)."The Economic Theory of Index Numbers and the Measurement of Input, Output, and Productivity."Econometrica, 50:6, pp. 1393-414.

Caves, D. W., L. R. Christensen, \& W. E. Diewert.(1982b). "Multilateral Comparisons of Output, Input, and Productivity Using Superlative Index Numbers."The Economic Journal, 92:365, 73-86.

Coelli, T. J. (1994). A Guide to FRONTIER Version 4.1: A computer Program for Stochastic Frontier Production and Cost Function Estimation, mimeo, Department of Econometrics, University of New England, Armidale. ISSN 1327-435X, ISBN 186389 4969, http://www.une.edu.un/econometric/cepawp.htp

Coelli, T. J D. S. P., Rao \& G. E. Battese (1998). An Introduction tficfefncy and Productivity Analysis (Kluwer Academic Publishers: Boston, (1998), CH. 6, Ch 3.

Coelli, T. J. \& D. S. P. Rao. (2005). "Total Factor Productivity Growth in Agriculture: A Malmquist Index Analysis of 93 Countries, 1980-2000." Agricultural Economics, 32:s1, 115-34. 


\section{Macrothink}

Journal of Agricultural Studies

ISSN 2166-0379

2013, Vol. 1, No. 1

Coelli, T.J. et al. (2005). An Introduction to Efficiency and Productivity Analysis. New York,United States: Springer.

Coelli, T. J. \& D. S. P. Rao. (2005). "Total Factor Productivity Growth in Agriculture: A Malmquist Index Analysis of 93 Countries, 1980-2000." Agricultural Economics, 32:s1, 115-34.

Coelli, T. J., L. Lauwers, \& G. Van Huylenbroeck. (2007). "Environmental Efficiency Measurement and the Materials Balance Condition", Journal of Productivity Analysis, 28:1, pp.3-12

Cohen, JI. (1994). "Biotechnology Priorities, Planning and Policies: A Framework for Decision Making”, ISNAR Research Report No 6.

Coviello, Manlio F., et al. (2005). Biocombustibles líquidos para transporte en América Latina y el Caribe. CEPAL-Colección de Documentos de proyectos. Copyright $@$ Naciones Unidad, diciembre de 2008. Todos los derechos reservados. Impreso en Naciones Unidas, Santiago de Chile.

Craig, B.J., Pardey, P.G. \& Roseboom, J. (1997). "International productivity patterns: accounting for input quality, infrastructure, and research”, American Journal of Agricultural Economics, 79, 1064-1077.

Chung, Y. H., R. Fare, \& S. Grosskopf.(1997). "Productivity and Undesirable Outputs: A Directional Distance Function Approach." Journal of Environmental Management, 51:3, pp. 229-40.

Chavas, J.P. (2001).“An International Analysis of Agricultural Productivity”, in L. Zepeda, ed., Agricultural Investment and Productivity in Developing Countries, FAO, Rome.

Dowd, B. M., D. Press, \& M. L. Huertos. (2008). "Agricultural Non-Point Source Water Pollution Policy: The Case of California's Central Coast." Agriculture, Ecosystems \& Environment, 128:3, 151-61.

EUROPEAN COMMISSION, EC. (2005). "New Perspective on the knowledge based bioeconomy: A conference report”, European Commission, Brussels, Belgium, 2005.

Elobeid, A., S. Tokgoz, D.J. Hayes, B.A. Babcock, \& C.E. Hart. (2007). “The Long-Run Impact of Corn-Based Ethanol on the Grain, Oilseed, and Livestock Sectors: A Preliminary Assessment.” AgBioForum 10(1):11-18.

Elobeid, Amaniet. Al. (2007).“The Long-Run Impact of Corn-Based Ethanol on the Grain, Oilseed, and Livestock Sectors with Implications for Biotech Crops.AgBioForum, 10 (1): 11-18.

Färe, R. \& S. Grosskopf. (1994). Cost and Revenue Constrained Production. New York: Springer-Verlag. 


\section{MInstitute ${ }^{\text {Mit }}$}

Journal of Agricultural Studies

ISSN 2166-0379

2013, Vol. 1, No. 1

Färe, R., S. Grosskopf, C. A. K. Lovell, \& C. Pasurka. (1989). "Multilateral Productivity Comparisons When Some Outputs Are Undesirable: A Nonparametric Approach." The Review of Economics and Statistics, 71:1, 90-98.

Färe, R. S. Grosskopf, M. Norris, \& Z. Zhang, (1994). "Productivity Growth, Technical Progress and Efficiency Changes in IndustrialisedCountries.:" American Economic Review, 84 (1994), 66-83.

Fulginiti, L. \& R. Perrin. (1993). "Prices and Productivity in Agriculture”, Review of Economics and Statistics, 75, 471-482.

Fulginiti, L.E. \& Perrin, R.K. (1997)."LDC agriculture: Nonparametric Malmquist productivity indexes”, Journal of Development Economics, 53, 373-390.

Fulginiti, L.E. \& Perrin, R.K. (1998).“Agricultural productivity in developing countries”, Journal of Agricultural Economics, 19, 45-51.

Fulginiti, L.E. \& Perrin, R.K. (1999). "Have Price Policies Damaged LDC Agricultural Productivity?”, Contemporary Economic Policy, 17, 469-475.

García Camús, Juan Manuel, García Laborda, José Angel.(2006).Biocarburanteslíquidos: Biodiésely Bioetano. http//www.madrimaasd.org

Hoang, Viet-Ngu\& Coelli Tim., (2009).Measurement of Agricultural Total Factor Productivity Growth incorporating environmental factor: A Nutrients balance approach. School of Economics, The University of Queensland, St Lucia, 4072, Queensland, Austria, 23/05/2009. Working Paper No WP03/2009 ISSN No 1932-4398.http://ageconsearch.umn.edu/handle/47636

Köhlin, G. (2003).Fuelwood - Crisis or Balance?, Workshop Proceedings (editor), Göteborg University.

Lusigi, A. \& Thirtle, C. (1997). "Total factor productivity and the effects of R\&D in African agriculture”, Journal of International Development, 9, 529-538.

Leudena, Carlos E. (2010). Agricultural Productivity Growth, Efficiency Change and Technical Progress in Latin America and Caribbean. IDB Working paper serieNo.IDB-WP-186. http://idbdocs.iadb.org/wsdocs/getdocument.aspx?docnum=35838847

Lanteri, Luis N. (2002). Productividad, desarrollo tecnológico y eficiencia. la propuesta de los índices Malmquist. Anales de la Asociación Argentina de Economía Política, XXXVII Reunión Anual, Tucumán, Argentina [en línea] www.aaep.org.ar

Martin, W. \&Mitra, D. (1999)."Productivity Growth and Convergence in Agriculture and Manufacturing”, Agriculture Policy Research Working Papers, No. 2171, World Bank, Washington D.C.

Nam, C. W., R. Parsche, D. M. Radulescu, \& M. Schope, (2007)."Taxation of Fertilizer, Pesticides and Energy Use for Agricultural Production in Selected Eu Countries."European Environment, 17, 267-84. 
Nin, A., Arndt, C. \&Preckel, P.V., (2003).“Is agricultural productivity in developing countries really shrinking? New evidence using a modified nonparametric approach”, Journal of Development Economics, 71, 395-415.

OECD.(2006). Annual report 2006, Organization for Economic Co-Operation and Development.http://www.oecd.org/home/0,2987,en_2649_201185_1_1_1_1_1,00.html

OECD. (2009). Journal on Development: Development Co-operation Report 2009 Volumen 10 issue 1 summary in Spanish ISBN 978-92-64-055056 (C) OECD 2009.

Pretty, J., C. Brett, D. Gee, R. Hine, C. Mason, J. Morison, M. Rayment, G. Van Der Bijl, \& T. Dobbs.(2001). "Policy Challenges and Priorities for Internalizing the Externalities of Modern Agriculture."Journal of Environmental Planning and Management, 44, 263-83.

Pittman, R. W., (1983)."Multilateral Productivity Comparisons with Undesirable Outputs."The Economic Journal, 93:372, 883-91.

Rao, D.S.P. \& Coelli, T.J., (1998). "Catch-up and Convergence in Global Agricultural Productivity, 1980-1995", CEPA Working Papers, No. 4/98, Department of Econometrics, University of New England, Armidale, pp. 25.

Rao, D. S. Prasada, Christopher J. O'Donnell, \& George E. Battese. (2003). "Metafrontier Functions for the Study of Inter-Regional Productivity Differences.” Working Paper no. 01/2003, Centre for Efficiency and Productivity Analysis, School of Economics, The University of Queensland.

Reinhard, S., C. A. Knox Lovell, \& G. J. Thijssen. (2000). "Environmental Efficiency with Multiple Environmentally Detrimental Variables; Estimated with Sfa and Dea." European Journal of Operational Research, 121:2, 287-303.

Rozakis, S., \& J.C. Sourie. (2005). "Micro-economic Modelling of Biofuel System in France to Determine Tax Exemption Policy under Uncertainty.”Energy Policy 33(2):171-182.

Shaik, S. \& R. K. Perrin. (2001). "Agricultural Productivity and Environmental Impacts: the Role of Non-Parametric Analysis."American Agricultural Economics Association Meetings. American Agricultural Economics Association (AAEA): Chicago.

Scheel, H. (2001). Undesirable Output in Efficiency Valuations;European Journal of operational Research.132:2, 400-10.

Suhariyanto, K. \& Thirtle, C. (2001). “Asian Agricultural Productivity and Convergence”, Journal of Agricultural Economics, 52, 96-110.

Suhariyanto, K., Lusigi, A. \& Thirtle, C. (2001). "Productivity Growth and Convergence in Asian and African Agriculture”, in Asia and Africa in Comparative Economic Perspective, P. Lawrence and C. Thirtle, eds. London: Palgrave, 258-74.

Tong, Haizhi, et. al, (2009). Chinese Regional Agricultural Productivity: 1994-2005. Contributed Paper prepared for presentation at the International Association of Agricultural Economists’ 2009 Conference, Beijing, China, August 16-22, 2009. 


\section{Macrothink}

Journal of Agricultural Studies

ISSN 2166-0379

2013, Vol. 1, No. 1

Tyteca, D. (1996). On the Measurement of the Environmental Performance of Firms- a Literature Review and a Productive of Firms- Concepts and Empirical Results, Journals of Productivity Analysis, 8:2, 183-07

Tyteca, D. (1997). "Linear Programming Models for the Measurement of Environmental Performance of Firms-Concepts and Empirical Results." Journal of Productivity Analysis, 8:2, 183-97.

Tokgoz, S., A. Elobeid, J.F. Fabiosa, D.J. Hayes, B.A. Babcock, T-H.Yu, F. Dong, C.E. Hart, \& J.C.Beghin. (2007). "Emerging Biofuels: Outlook of Effects on U.S. Grain, Oilseed, and Livestock Markets.” CARD Staff Report 07-SR 101, Center for Agricultural and Rural Development, Iowa State University.

Trigo, J. Eduardo. (2011). "The Bio Economy in Latin America and the Caribbean: Towards a socio economic research agenda”, LAC regional IAA, Inter. Symposia on the Bio Economy, 19-20 September 2011, Cali Colombia.

Trueblood, M.A. \& Coggins, J. (2003). Intercountry Agricultural Efficiency and Productivity: A Malmquist Index Approach, mimeo, World Bank, Washington DC.

Van Der Brandt, H. M. P. \& H. P. Smit. (1998). "Mineral Accounting: The Way to Combat Eutrophication and to Achieve the Drinking Water Objective." Environmental Pollution, 102, 705-09.

Wiebe, K., Soule, M., Narrod C., \& Breneman, V. (2000). Resource Quality and Agricultural Productivity: A Multi-Country Comparison, mimeo, USDA, Washington DC.http://www.oecd.org/home/0,2987,en_2649_201185_1_1_1_1_1,00.html

Yaisawarng, S. \& D. J. Klein. (1994). "The Effects of Sulfur Dioxide Controls on Productivity Change in the U.S. Electric Power Industry." The Review of Economics and Statistics, 76:3, 447-60.

Yeboah, Osei., et., (2011). Measurements of Agricultural Productivity and Efficiency Gains from NAFTA. Selected Paper prepared for presentation at the Southern Agricultural Economics Association Annual Meeting, Corpus Christi, TX, February 5-8, 2011

Zhang, Z., D. Vedenov, \& M. Wetzstein. (2007). “Can the U.S. Ethanol Industry Compete in the Alternative Fuels Market?” Agricultural Economics, 37(1):105-112.

Zúniga, G. Carlos A. (2011). Texto básico de economía agrícola: Su Importancia para el Desarrollo Local Sostenible.ISBN: 978-99964-0-049-0. Registro de propiedad intelectual No OL-019-2011. Charter II, pag32-86. Disponible On Line at:http://purl.umn.edu/111604 
Appendix

Table 4: Annual Mean BTFP Change, Bio Economy Technical Efficiency Change, and Bio Technical Efficiency Change, Bio Technical Change

\begin{tabular}{|c|c|c|c|}
\hline Year* & btfpch & beffch & btechch \\
\hline 1981 & 1.411 & 1.073 & 1.315 \\
\hline 1982 & 0.997 & 1 & 0.997 \\
\hline 1983 & 0.997 & 1 & 0.997 \\
\hline 1984 & 1.117 & 1 & 1.117 \\
\hline 1985 & 0.933 & 1 & 0.933 \\
\hline 1986 & 1.359 & 0.948 & 1.434 \\
\hline 1987 & 0.841 & 0.989 & 0.851 \\
\hline 1988 & 0.868 & 1.067 & 0.814 \\
\hline 1989 & 1.036 & 1 & 1.036 \\
\hline 1990 & 1.008 & 0.996 & 1.012 \\
\hline 1991 & 0.857 & 1.004 & 0.853 \\
\hline 1992 & 0.837 & 1 & 0.837 \\
\hline 1993 & 1.324 & 1 & 1.324 \\
\hline 1994 & 0.88 & 0.991 & 0.888 \\
\hline 1995 & 1.17 & 1.009 & 1.159 \\
\hline 1996 & 0.869 & 1 & 0.869 \\
\hline 1997 & 1.1 & 0.971 & 1.133 \\
\hline 1998 & 0.89 & 1.029 & 0.865 \\
\hline 1999 & 1.028 & 0.987 & 1.042 \\
\hline 2000 & 0.818 & 1.013 & 0.807 \\
\hline 2001 & 1.163 & 1 & 1.163 \\
\hline 2002 & 0.761 & 1 & 0.761 \\
\hline 2003 & 1.076 & 1 & 1.076 \\
\hline 2004 & 0.866 & 0.98 & 0.884 \\
\hline 2005 & 1.353 & 1.02 & 1.326 \\
\hline 2006 & 0.905 & 1 & 0.905 \\
\hline 2007 & 1.267 & 1 & 1.267 \\
\hline mean & 1.011 & 1.003 & 1.009 \\
\hline
\end{tabular}

*Note that 1981 refers to the change between 1980 and 1981, etc. 


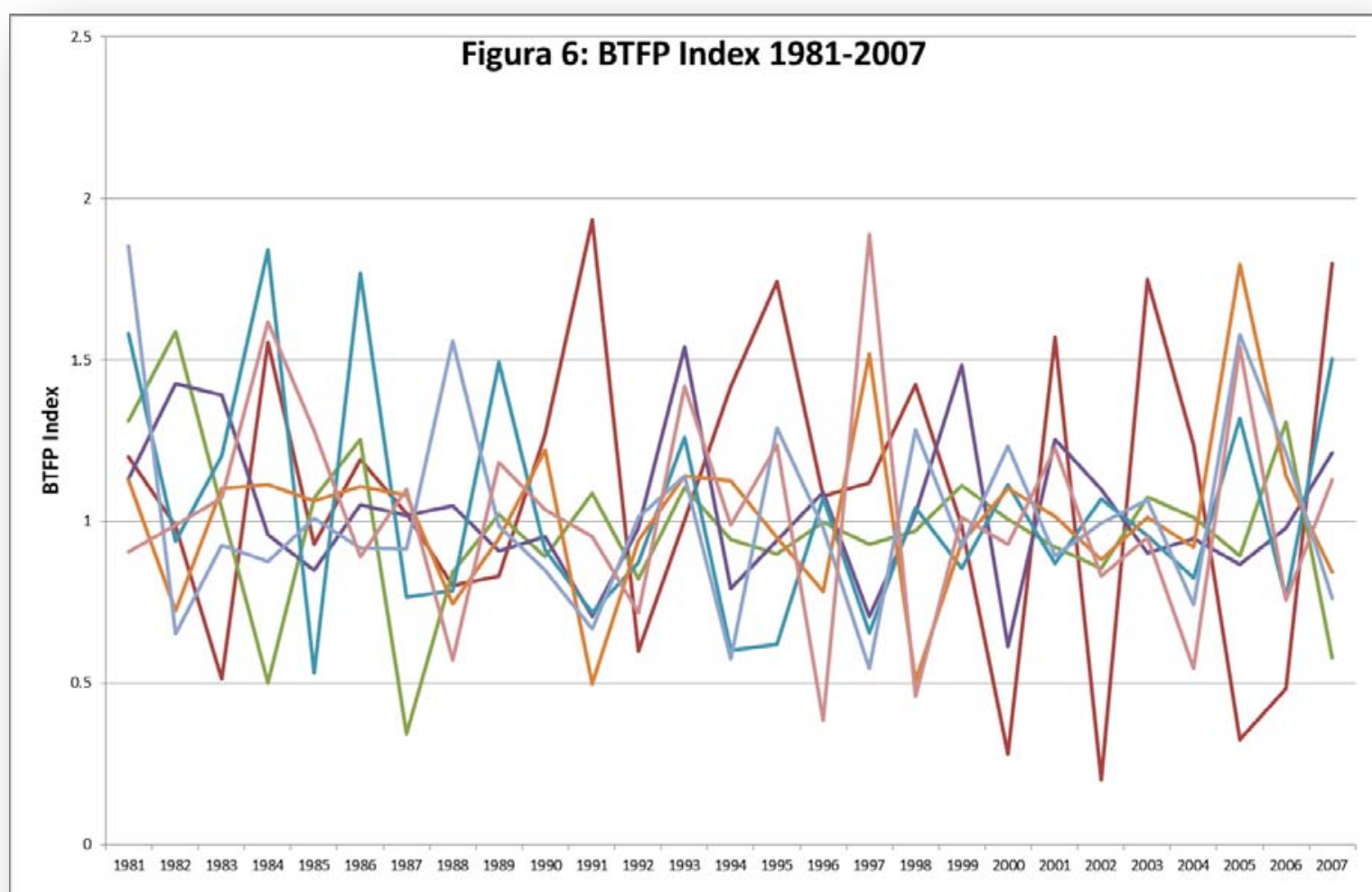

—Belize — Costa Rica —El Salvador — Guatemala — Honduras — Nicaragua — Panamá

\section{Copyright Disclaimer}

Copyright reserved by the author(s).

This article is an open-access article distributed under the terms and conditions of the CreativeCommons Attribution license (http://creativecommons.org/licenses/by/3.0/). 